\title{
THE IMPACT OF RIVERBED EROSION ON THE TECHNICAL CONDITION OF WATER ENGINEERING STRUCTURES: THE EXAMPLE OF VISTULA RIVER REACH NEAR THE OUTLET OF WILANÓWKA STREAM
}

\author{
Łukasz Krysiak $^{凶}$ \\ Faculty of Building Services, Hydro and Environmental Engineering, Warsaw University of Technology, Warsaw
}

\begin{abstract}
Design and maintenance of most water engineering structures is inseparably linked to a set of relevant environmental conditions. Since the latter undergo gradual transformations, the former are also dynamic. This paper provides a brief analysis of deep riverbed erosion occurring in the Vistula river reach near the outlet of Wilanówka stream. The resulting changes of the valley's geomorphology are explained, as well as the detrimental effects they have on the technical condition and functionality of the river engineering structures and the levees within the analysed river reach. Selected requirements for water engineering structures according to the Polish regulations are discussed.
\end{abstract}

Key words: river engineering structures, sediment dredging, erosion

\section{INTRODUCTION}

Warsaw, like many large human settlements, is located adjacent to a major watercourse. The economic importance of Vistula river to the city includes:

- satisfying the living needs of inhabitants for drinking and utility water - about $70 \%$ of city's water supply comes from Vistula (Kocot, 2009),

- supplying the cooling water for Siekierki CHP Plant,

- mining of river sand to be used in construction,

- recreation,

- to a lesser extent - inland navigation, mainly for tourism and minor passenger transport.

Inevitably, the tight link of the city to the river results in the threat of occasional flooding, as approximately $23 \%$ of the entire urban area of Warsaw is located within flood hazard zones (Magnuszewski, Gutry-Korycka, \& Mikulski, 2012a). In order to mitigate that risk and to use the riches supplied by rivers efficiently, it is necessary to limit the dynamics of hydrological processes, such as changes in the geometry of the riverbed and the river reach as a whole, or periodic significant shifts in water levels. Engineering measures undertaken to this purpose constitute the so-called river engineering (regulation, training). Its main aim is to create steady water and debris flow conditions and to enable free and quick surface ice movement. It is achieved by deliberate reshaping of the riverbed's cross-section and river's longitudinal profile by sediment dredging or construction of hydrotechnical structures (dams) (Mamak \& Zgierski, 1958). Presently, Vistula valley within the city is highly transformed relative to its natural state. 
The introduction of dams and mining of sediments are commonly known to interfere with the flow characteristics and sediment transport occurring in rivers. The latter is a natural process remaining in relative equilibrium, which is easily disrupted by human activity, as described by Kondolf (1997). As shown in that paper, a local initiation of erosion, either by an increase in flow energy (river engineering) or direct sediment removal (excavation), induces a propagating channel incision. Local pits in the riverbed modify the formerly stable longitudinal profile, creating a steep gradient at the upstream end of the pit. The sediment transport of the river adjusts to that disruption in a process called headcutting, resulting in a propagation of the pit, both downstream and upstream, for up to kilometres within decades (Scott, 1973).

Progressing erosion results in damages both to the environment and man-made infrastructure located inside the valley. A several-metre incision, which reaches structures founded in the riverbed, modifies their support conditions and might result in sinking or instability. The most urgent cases are linked to bridge undermining, as illustrated by numerous examples (Kondolf, 1997).

The Vistula river reach chosen for this analysis might serve as an example to discuss the above-mentioned mechanisms. Estimations of deep erosion rate can be made. Resulting apparent deterioration of the river engineering infrastructure is observable. Some critical insight into the design of dams and levees can be proposed.

\section{DESIGN OF WATER ENGINEERING STRUCTURES}

River engineering structures, positioned perpendicular or parallel to the river current, are called wing dams and longitudinal dams respectively. Their purpose is to create a concentration of the water flow in a relatively stable riverbed, cut off side channels and promote land accumulation in them, create and stabilize banks in new locations. Both types of dams, being constantly subjected to dynamic effects of the water flow, should offer sufficient resistance and have shapes, sizes and positioning appropriate for the designed river course (Mamak \& Zgierski, 1958). It is crucial that they do not greatly influence high discharge water flows, especially during major floods, so their crests are usually lower than the statistical average water level observed in the particular river cross-section (Fig. 6).

Levees, the flood-protecting embankments parallel to the river banks, are classified as water engineering structures periodically damming up water within the riverbed. The spacing of the two levees has to be sufficient, so that great discharges during highwater can safely transition along the entire watercourse (Mamak \& Zgierski, 1958). According to the Ordinance of The Minister of Environment dated 20 April 2007 (Dz.U. $2007 \mathrm{nr} 86$ poz. 579) levees belong to the major water engineering structures group, as their failure might endanger large areas and the environment. The requirements, that the levees must satisfy are, according to the decree:

- soil embankment slope stability (§ 39),

- safe crest elevation of permanent hydrotechnical structures $(\S 52)$.

The above-mentioned criteria should be verified in modelled conditions of a design flood, with water discharge reaching design value $\left(Q_{m}\right)$ or control value $\left(Q_{k}\right)$ with specified yearly exceeding probability, characteristic for the particular river cross-section. Requirements regarding levee crest elevation, depending on their importance class, are listed in Table 1. The middle Vistula valley, including Warsaw city, is protected by levees of classes I and II (Krukowicz, 2010).

The overview of selected design requirements for water engineering structures presented above indicates that they are strictly dependent on local environmental conditions. It is therefore crucial to perform a thorough hydrological analysis of the river's catchment area and the valley section, where the structures are intended to be introduced. This analysis includes measurements of flow parameters (discharges and water levels), registered daily at river gauging stations. Historical data encompassing decades of records makes it possible to assess and model high water discharges with specified yearly exceeding probability, which are used to calculate corresponding flood water levels by hydraulic modelling. The same applies to average water levels, which determine appropriate elevation of the crests of river engineering structures. 
Krysiak, Ł. (2018). The impact of riverbed erosion on the technical condition of water engineering structures: the example of Vistula river reach near the outlet of Wilanówka stream. Acta Sci. Pol. Architectura, 17 (4), 71-81. doi: 10.22630/ASPA.2018.17.4.42

Table 1. Safe crest elevation of permanent hydrotechnical structures above the water level-embankment dams and levees (Dz.U. $2007 \mathrm{nr} 86$ poz. 579)

\begin{tabular}{lcccc}
\hline \multirow{2}{*}{ Operating conditions } & \multicolumn{4}{c}{ Safe crest elevation above water level $[\mathrm{m}]^{\mathrm{a}}$} \\
\cline { 2 - 5 } & I class & II class & III class & IV class \\
\hline Maximum water levels & 2.0 & 1.5 & 1.0 & 0.7 \\
\hline Design discharge $\left(Q_{m}\right)$ & 1.3 & 1.0 & 0.7 & 0.5 \\
\hline Accidental conditions ${ }^{\text {b }}$ & 0.3 & 0.3 & 0.3 & 0.3
\end{tabular}

${ }^{a}$ Excluding the influence of waves - only considered when the levee spacing is greater than $3 \mathrm{~km}$.

${ }^{\mathrm{b}}$ Control water discharge $\left(Q_{k}\right)$ or the highest possible water level $\left(H_{m}\right)$, estimated based on analyses of possible causes, such as ice blocks and wind induced backwater

\section{VISTULA RIVER IN WARSAW - RIVER REACH NEAR THE OUTLET OF WILANÓWKA STREAM}

The characteristics of Vistula river in Warsaw has been the subject of numerous papers, including (Krukowicz, 2010; Kuźniar, 2011; Magnuszewski et al., 2012a). It is worth noting, that the spacing of levees in the centre of the city is significantly reduced. Upstream and downstream from Warsaw the levee spacing measures approximately $1,700 \mathrm{~m}$, while along the reach between km 511 and 514, near Poniatowski and ŚląskoDąbrowski bridges, it is narrowed to $470-480 \mathrm{~m}$. The width of the riverbed between the regulating structures is also the smallest in the same spot, measuring roughly $200 \mathrm{~m}$. As a result, this characteristic segment of the river earned the name "Warsaw Corset".

The analysed river reach is located near city's southern limits and outside dense urbanised areas, stretching from $\mathrm{km} 500$ to 507 . Levees are present along both banks, spaced at least $800 \mathrm{~m}$ apart, the reach is fully regulated. It serves as a source of sand for two mining companies ("Zawady" and "Pol-Bot") and as water supply for Siekierki CHP Plant; the Warszawa-Nadwilanówka river gauging station is also located within this reach (Fig. 1).

In order to assess potential geomorphology-changing processes a hydrological analysis has been performed, based on data registered by the river gauge in the 1967-2016 period. The data includes daily water level (called stage) $[\mathrm{m}]$ and estimated discharge $\left[\mathrm{m}^{3} \cdot \mathrm{s}^{-1}\right]$, it is based on a database presented and discussed in (Kuc, 2012).

\section{HYDROLOGICAL ANALYSIS}

The characteristics of a river reach related to the parameters of water flow can be simply represented by statistically obtained characteristic values of discharges and stages. The minimum discharge (LQ) observed during a year is usually about $200 \mathrm{~m}^{3} \cdot \mathrm{s}^{-1}$, while the

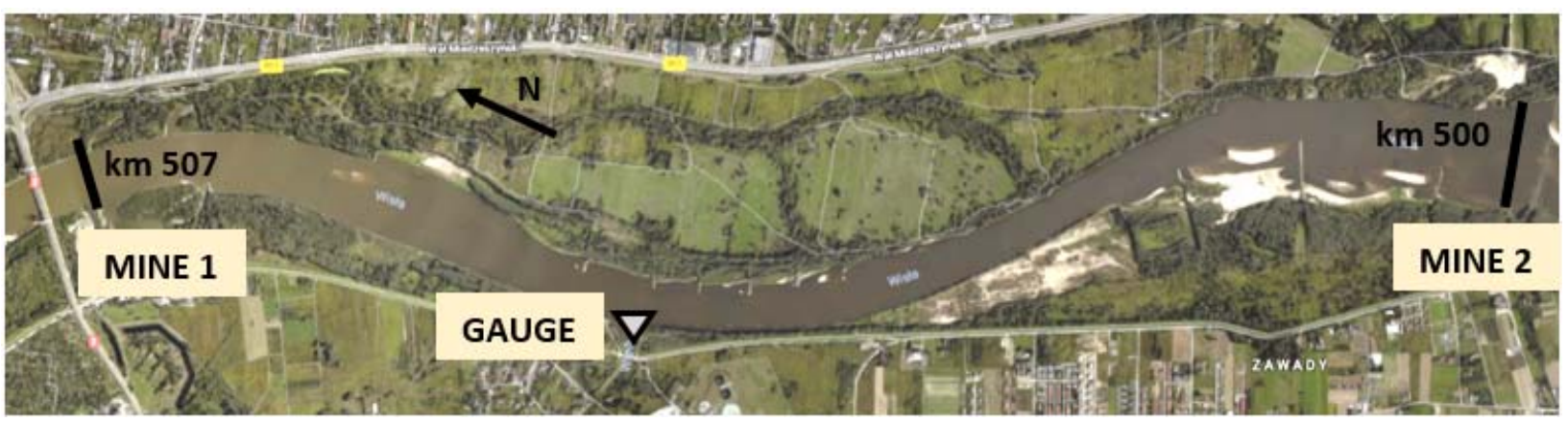

Fig. 1. Satellite image of the analysed river reach, including approximate $\mathrm{km}$, the locations of river gauging station Nadwilanówka (presently) and sand mining companies (www.google.pl/maps) 
Krysiak, Ł. (2018). The impact of riverbed erosion on the technical condition of water engineering structures: the example of Vistula river reach near the outlet of Wilanówka stream. Acta Sci. Pol. Architectura, 17 (4), 71-81. doi: 10.22630/ASPA.2018.17.4.42

maximum (HQ) can vary greatly depending on the intensity of flood events during that particular year. The highest discharges observed in Vistula river in Warsaw during the last century were $5,860 \mathrm{~m}^{3} \cdot \mathrm{s}^{-1}$ (year 1924), $5,650 \mathrm{~m}^{3} \cdot \mathrm{s}^{-1}(1960)$ and $5,898 \mathrm{~m}^{3} \cdot \mathrm{s}^{-1}(2010)$ (Magnuszewski et al., 2012a). Mean annual discharges (MQ) are typically between 500 and $650 \mathrm{~m}^{3} \cdot \mathrm{s}^{-1}$. Similarly, characteristic values of stages can be found, namely the yearly maximum (HW), average (MW) and minimum (LW), which are measured relative to an assumed zero of the river gauge. The values of characteristic stages in consecutive years are illustrated in the graph below (Fig. 2). In order to better represent general trends and to reduce occasional anomalies, presented values of LW and MW are averages calculated for 3 consecutive years, assigned to the middle year. Lines of best fit illustrate the approximate relation between time in years and characteristic stages.

The change in $\mathrm{LW}$ and MW values over years shows a clear decreasing tendency. It is not accompanied by a corresponding change in LQ and MQ values, which vary between stable limits during the entire analysed period. This indicates that stages corresponding to stable discharges, ranging from the minimum to the average, are gradually lower relative to the zero of the gauge. Such an observation evidences quickly progressing deep erosion of the riverbed between the river engineering structures. The graph shows short periods when the bottom is apparently rising, that are associated with years abundant in severe floods $(1980,1997-1998$, 2010). Higher discharges may provide more debris accumulation, but they do not influence the general decreasing trend.

High variations in HW levels, unlike LW and MW, mirror similar variations in discharge (HQ) in consecutive years. Additionally, the discharge during highwater is carried in the entire space available between the levees, not just in the regulated width. As a result, changes in HW (Fig. 2) cannot serve to assess the erosion of comparatively narrow riverbed segment.

It is not entirely correct to discuss changes in stages in time in isolation from discharge changes. As stated before, they are strictly connected, and this relation is presented using the so-called rating curves, which can be approximately drawn based on the data obtained at the gauging station. The curves representing relation $\mathrm{H}(\mathrm{Q})$ between stage and discharge at Nadwilanówka station, in selected years, are illustrated in Figure 3.

The relation between stages and discharges in the analysed cross-section has changed significantly

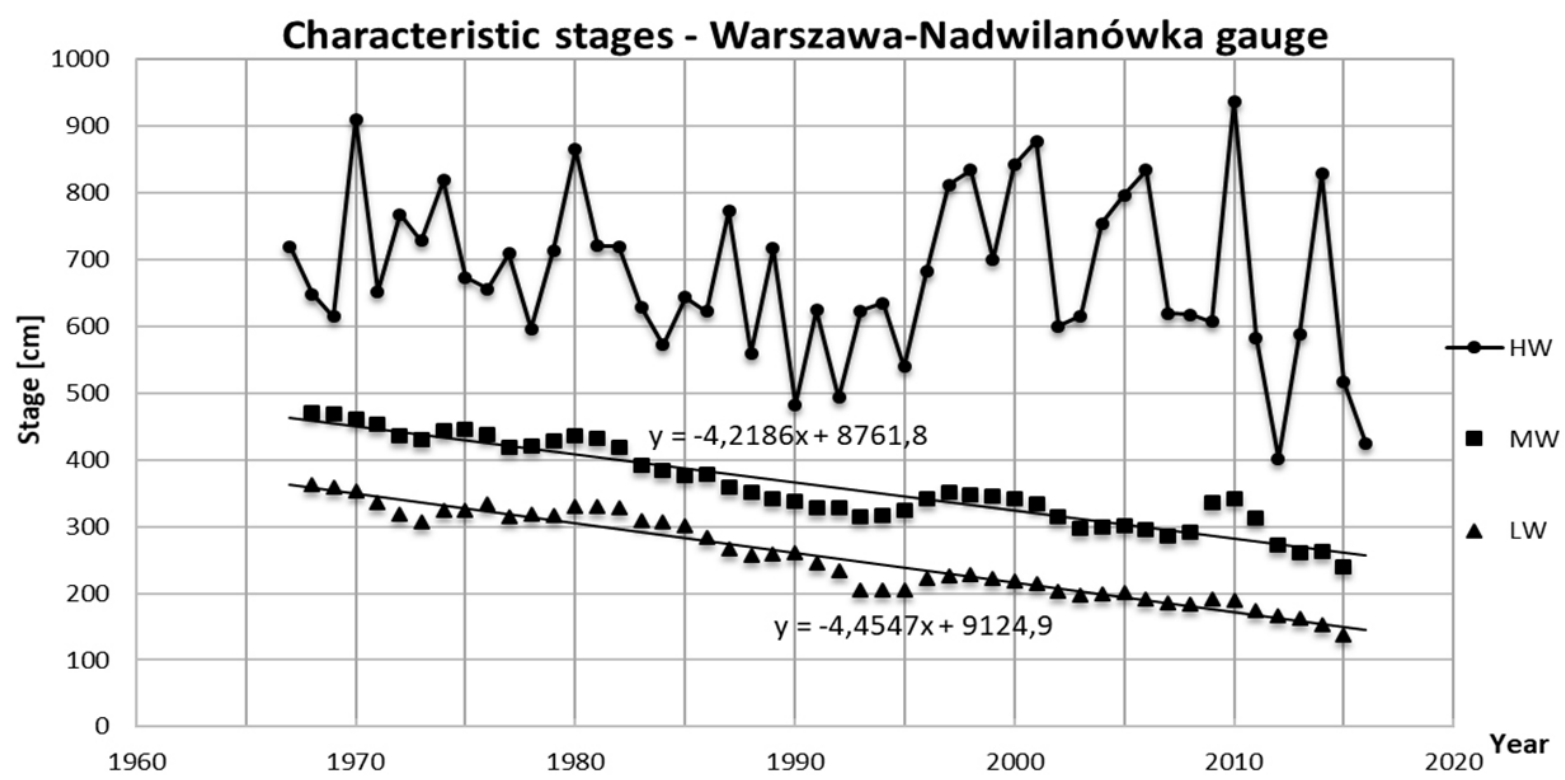

Fig. 2. Maximum (HW), average (MW) and minimum (LW) yearly water levels (stages) observed at Warszawa-Nadwilanówka river gauging station. LW and MW represented by 3-years averages assigned to the middle year 


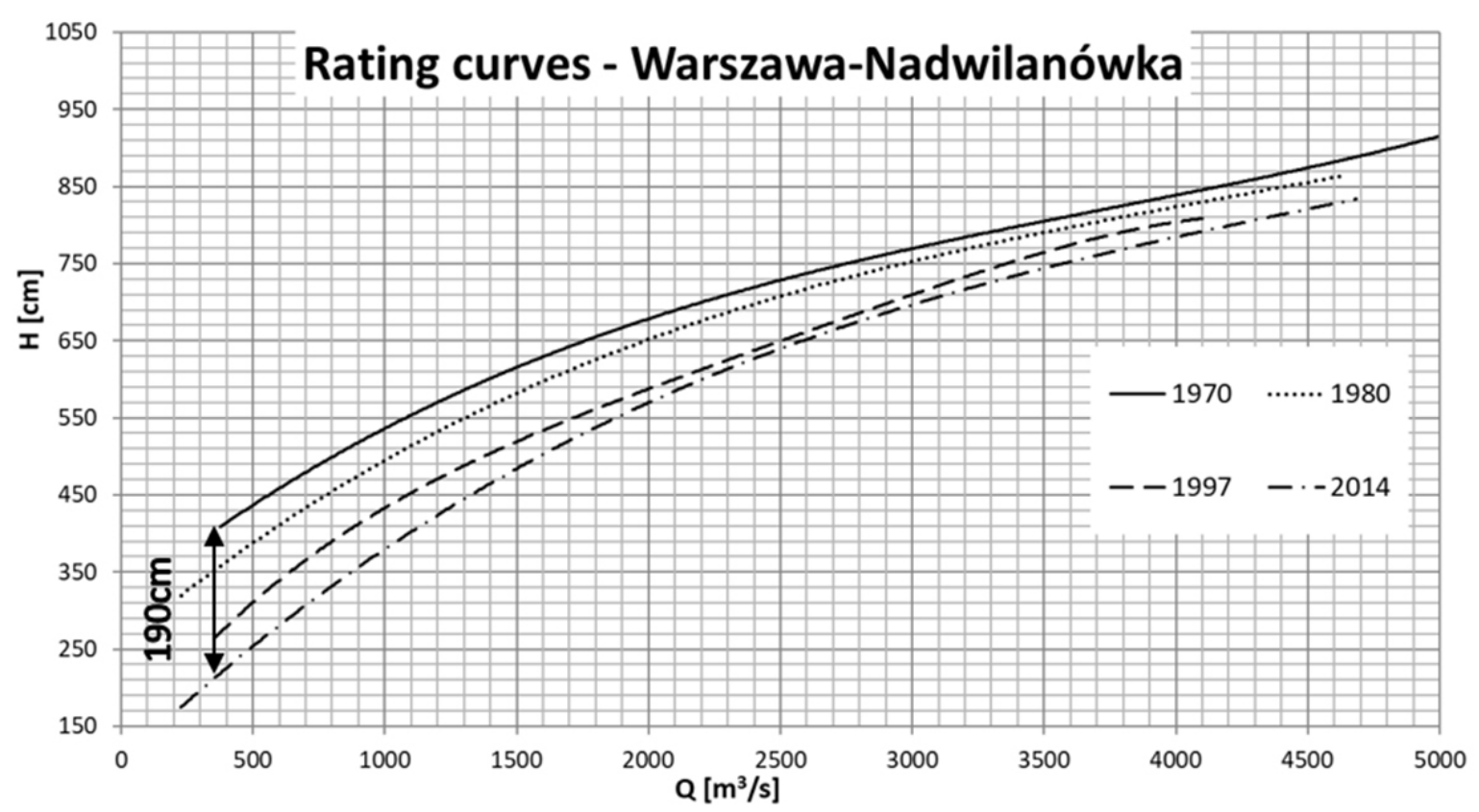

Fig. 3. Empirical rating curves based on daily records at Warszawa-Nadwilanówka river gauging station - selected years. Estimated value of the riverbed bottom elevation decrease in years 1970-2014 indicated. $H$-stage, $Q$ - discharge

over last 50 years, with more recent curves lowered relatively to their past equivalents. The shape of the curves within the low to average discharge range should be accurate, because such stable flow conditions are present during long periods in any year, and are not related to rapidly occurring phenomena, such as floods. On the other hand, shapes of the curves for high discharges, above $2,000-3,000 \mathrm{~m}^{3} \cdot \mathrm{s}^{-1}$, are likely less representative of reality, as they are approximated based on fewer data points.

The analyses above can provide a quantification of the intensity of the progressing deep riverbed erosion in the example river reach. Estimates of the erosion rate and the total bottom elevation decrease are listed in Table 2. The same trend is also visible in the results of bathymetric survey, presented in Kuźniar, Bednar- czyk, Krysiak, Rybczyński and Szablewski (2017), as the thalweg elevation gradually decreases. However, due to a limited scope of the survey no estimates could be produced.

The progression of man-induced deep erosion of Vistula river's bottom in Warsaw has been predicted and described inter alia already in 1938 (Pomianowski, 1938). Initially, the main cause was the narrow Warsaw Corset focussing water flow in limited width, thus generating higher flow velocities and enhanced ability to carry the bottom sediments, as modelled by Magnuszewski and Moran (2014). Simultaneously, heavy exploitation of the river sand, by 6-7 mines within the city recently, is considered by some to be the main factor locally contributing to erosion, exceeding the estimated volume of the natural sediment transport over

Table 2. Estimated deep riverbed erosion intensity in Warszawa-Nadwilanówka gauging station's cross-section

\begin{tabular}{lcc}
\hline \multirow{2}{*}{ Estimation method } & \multicolumn{2}{c}{ Estimated deep riverbed erosion, $1967-2016$} \\
\cline { 2 - 3 } & Average rate $\left[\mathrm{cm} \cdot \mathrm{year}^{-1}\right]$ & Total erosion $[\mathrm{cm}]$ \\
\hline LW level changes & 4.45 & 218 \\
\hline MW level changes & 4.22 & 207 \\
\hline Rating curve lowering & 4.32 & 212 \\
\hline
\end{tabular}


long time periods (Żelaziński, Brański, Kadłubowski, \& Werski, 2005). This ongoing process progresses towards upstream cross-sections, including the entire analysed river reach and further. The next gauging station upstream from Nadwilanówka, located in Gusin, experiences a slower erosion, at about $2 \mathrm{~cm}$ per year (Fal \& Dąbrowski, 2001).

It is predicted that depth of the riverbed will stabilize at a certain limit when it reaches a more cohesive geological stratum, located beneath the alluvium. The data recorded at Warszawa-Nadwilanówka gauging station during last years (2011-2016) suggest that it has not yet happened (Fig. 2). An apparent halt to erosion in 2008-2010 period was probably temporary and caused by a high intensity of floods and the sediment accumulation related to them.

\section{TECHNICAL CONDITION OF RIVER ENGINEERING STRUCTURES}

The analysed river reach is regulated by dams of various types, ages and structures, some of them are visible in the satellite image (Fig. 1). They have been originally designed based on assumed flow and riverbed conditions, which have changed significantly by now, as shown in this paper. As a result, some symptoms of deterioration of the river engineering structures are observed, as well as possible changes in the way they interact with the water and sediment flow. Several examples can be used to illustrate the phenomena.

The wing dams (groynes, spurs) "push" the main water current away from the bank and concentrate it inside an assumed cross-section. Their tips are located in an area of constantly turbulent water flow and they are founded on the bottom area subjected to concentrated riverbed erosion. Main body of the groynes is built of heavy material resistant to rapid water flows, the slopes (especially at the tip) have a mild inclination, foundations are traditionally constructed using mattresses made of fascine and rocks to prevent wash-outs (Fig. 4).

The groynes made of stone riprap positioned within the analysed river reach have deteriorated to various extents. Visual assessment of some of these structures (Kuźniar et al., 2017) suggests loss of initial shape and loosening of riprap, especially at the tips (Fig. 6a). Similar issues also affect groynes of different structure, including those with concrete slab slope facing (Fig. 6b).

Longitudinal dams and bank-protecting structures serve to stabilize the position of the concave bank, which is normally exposed to erosion. Similarly to the tips of

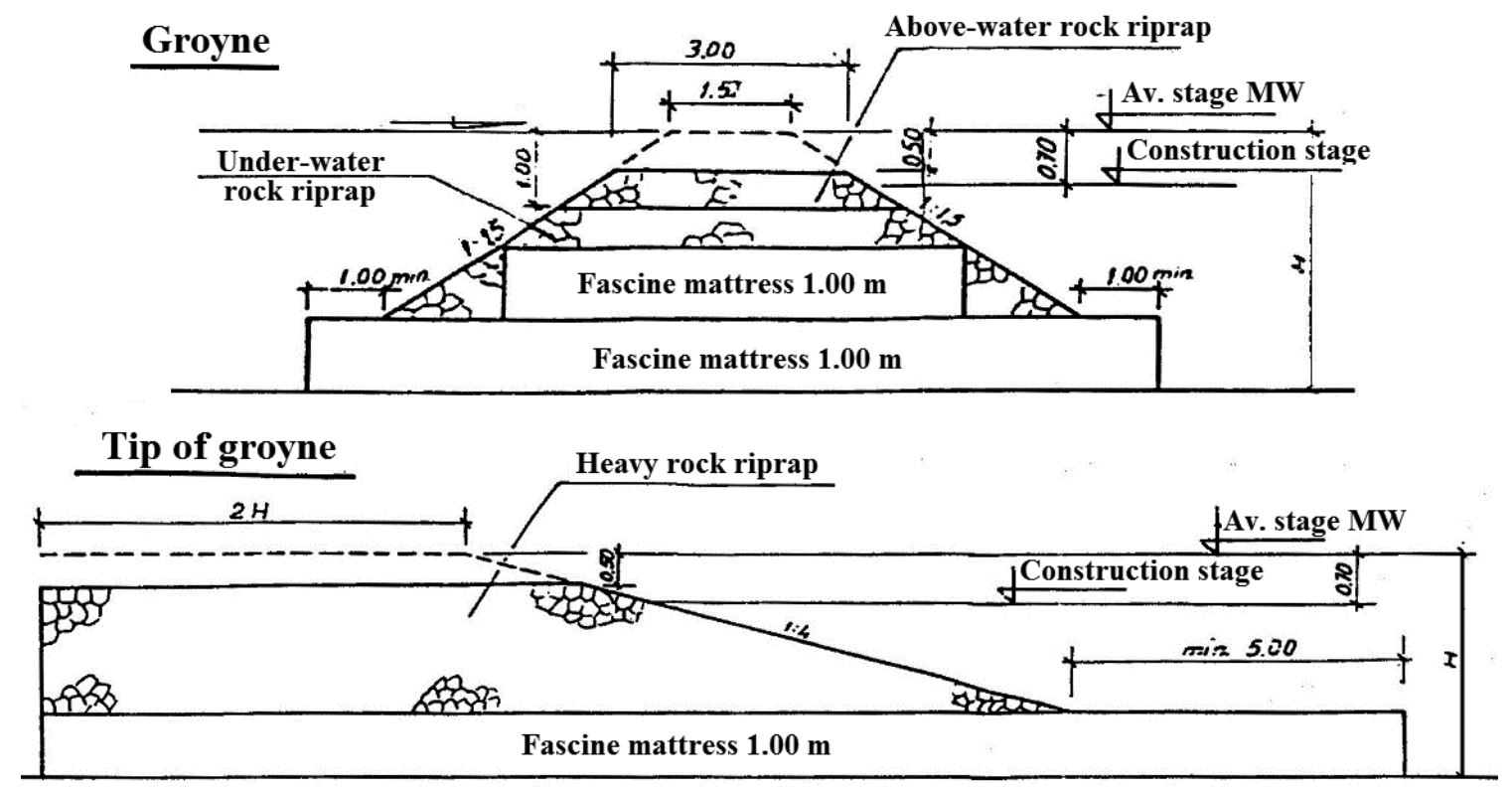

Fig. 4. Cross-section of a wing dam (top) and its tip (bottom) (RZGW, 1990s) 
Krysiak, Ł. (2018). The impact of riverbed erosion on the technical condition of water engineering structures: the example of Vistula river reach near the outlet of Wilanówka stream. Acta Sci. Pol. Architectura, 17 (4), 71-81. doi: 10.22630/ASPA.2018.17.4.42

the groynes, they are subject to the dynamic action of the water current and often founded in an area of concentrated bottom erosion. Their slopes are covered with heavy stone riprap and shaped using mild inclinations. Foundations are again made of fascine mattresses (Fig. 5).
Visual assessment of the bank-protecting structures in the analysed river reach suggests that they undergo degradation at varied rates. It affects rock riprap structures and walls built of concrete sheet piles (Fig. 6c, 6d).

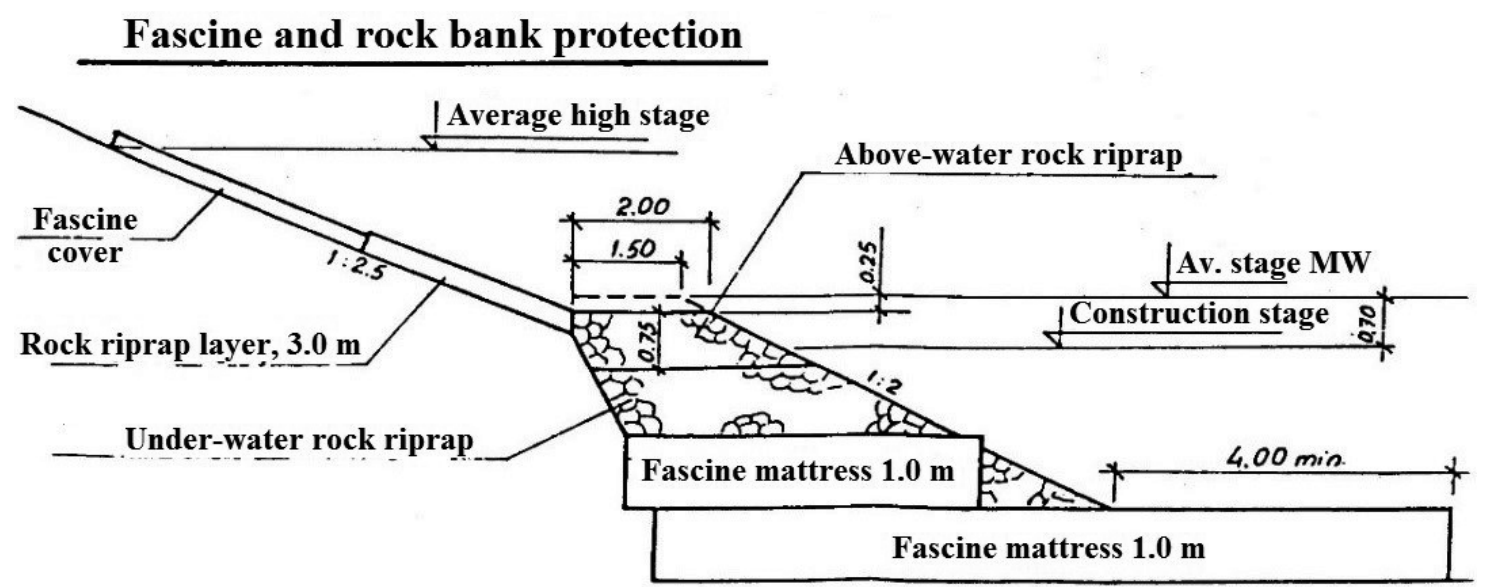

Fig. 5. Cross-section of bank-protection (RZGW, 1990s)
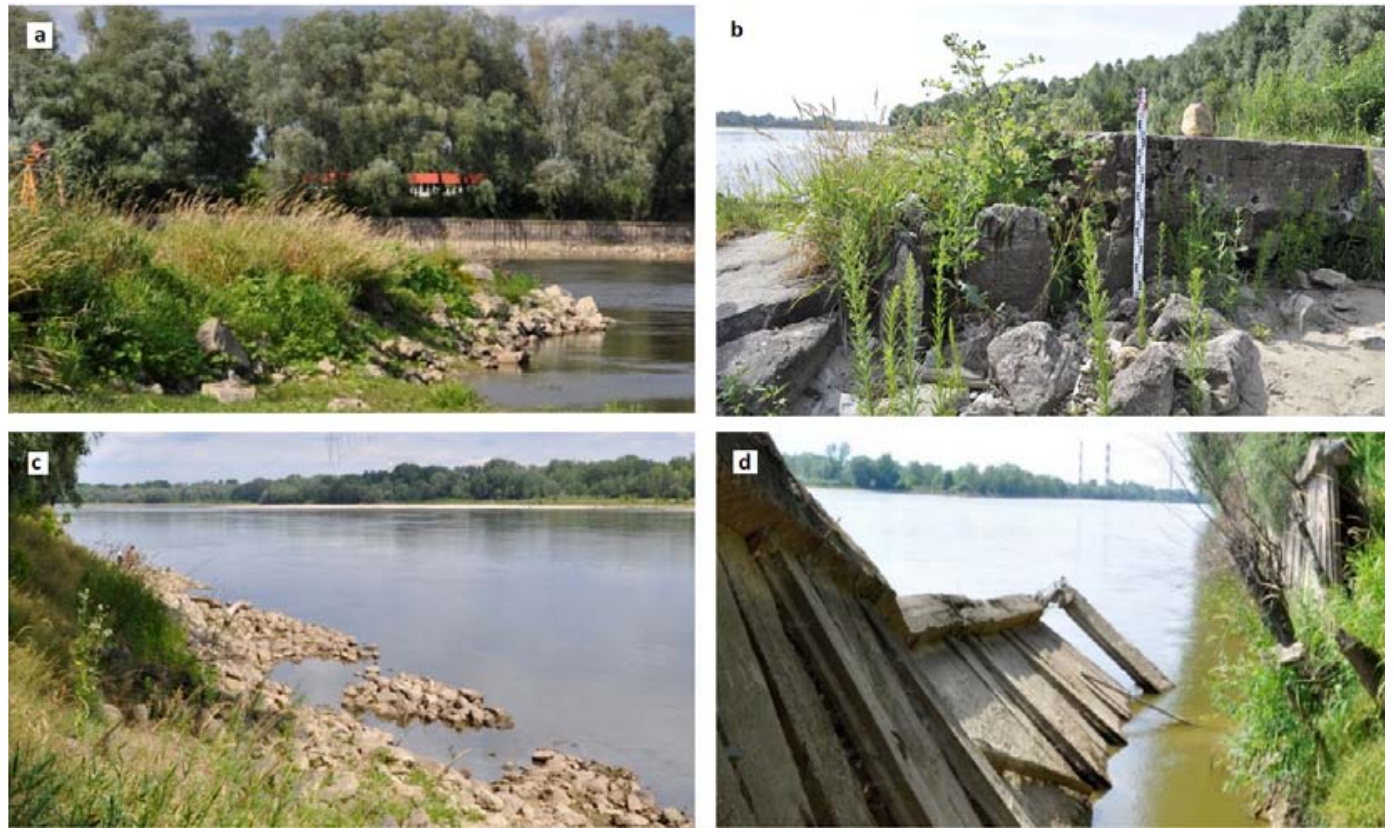

Fig. 6. River engineering structures (Kuźniar et al., 2017): a - left bank groyne, about $501.50 \mathrm{~km}$, loosened stone riprap and irregular shape of the structure; b - left bank groyne, about $506.50 \mathrm{~km}$, fault in the concrete body of the structure measuring approximately $80 \mathrm{~cm}$, concrete slope facing destroyed; c - left bank protection, about $504.50 \mathrm{~km}$, loosened stone riprap and sliding of loose boulders; $\mathrm{d}$ - right bank protection wall, about $501.40 \mathrm{~km}$, loss of stability of segments of the concrete sheet pile wall 
Krysiak, Ł. (2018). The impact of riverbed erosion on the technical condition of water engineering structures: the example of Vistula river reach near the outlet of Wilanówka stream. Acta Sci. Pol. Architectura, 17 (4), 71-81. doi: 10.22630/ASPA.2018.17.4.42

To represent the condition of the river regulation structures within the analysed reach more broadly, levelling measurements of their crests' elevations have been carried out. The results have been compared to records of the "EWIKOR" archives - a system for gathering of data related to river engineering structures in middle Vistula reach, used by the former ODGW in Poland during 1980s and 1990s. Selected observations are listed in Table 3.

Crests at the tips of the groynes located within the analysed river reach appear to be sinking, the decrease in elevation reaches up to $2 \mathrm{~m}$ (destruction of the structure). Most river regulation structures show symptoms of instability, such as slope sliding, loose boulders, loss of shape, washouts, destruction of slope facing and collapse of sheet piles. One of the factors contributing towards the deterioration of the structures is deep riverbed erosion, which results in washouts and decreasing elevation. Their foundations, made of fascine mattresses (Figs. 4, 5) are probably gradually sinking following the changing elevation of the riverbed bottom, while their original shape is likely distorted. The concrete sheet pile walls (Fig. 6d) are subjected to new loading conditions, as stabilizing forces related to water levels and soil depth on the riverbed side have significantly decreased.

\section{EFFECTIVENESS OF FLOOD PROTECTION}

Deep riverbed erosion on its own should not be detrimental to the ability of the valley to safely carry flood discharges between the levees, because, theoretically, it increases the area of the cross-section available for water and sediment flow. Changes in the rating curves over years (Fig. 3) seem to support this assumption, as stages corresponding to high discharges have gradually decreased, although not as much as in the low-medium discharge range. However, it should be

Table 3. Measurements and results of the visual assessment of selected regulation structures within analysed river reach (Kuźniar et al., 2017)

\begin{tabular}{lccllc}
\hline \multirow{2}{*}{$\begin{array}{l}\text { Structure type } \\
\text { Groyne }\end{array}$} & Bank & $\mathrm{km}$ & Technical condition & Crest elevation [m Kr.] \\
\hline Groyne & $\mathrm{L}$ & 501.50 & Loosened riprap & 2016 & Past (year) \\
\hline Groyne & $\mathrm{L}$ & 506.50 & $\mathbf{8 0} \mathrm{cm}$ fault in crest, concrete slope facing destroyed & 80.15 & $81.00(1971)$ \\
\hline Groyne & $\mathrm{L}$ & 500.50 & Very good, bushes and tree growth & 80.85 & $81.97(1993)$ \\
\hline Groyne & $\mathrm{L}$ & 501.00 & Very good, newly refurbished, used as ferry pier & 80.69 & - \\
\hline Groyne & $\mathrm{L}$ & 502.00 & $\begin{array}{l}\text { Loosened riprap, sliding of the slope, accumulation of } \\
\text { sediments and forest growth in the cut-off riverbed area }\end{array}$ & 82.53 & $82.32(1988)$ \\
\hline Groyne & $\mathrm{L}$ & 507.00 & $\begin{array}{l}\text { Tip destroyed, 2 m fault in the crest (concrete sheet pile } \\
\text { structure) }\end{array}$ & 78.75 & $81.05(1971)$ \\
\hline Bank protection & $\mathrm{L}$ & $504.30-504.50$ & Loosened riprap, sliding of the slope & 80.70 & $80.30(1987)$ \\
\hline Bank protection & $\mathrm{L}$ & 504.65 & Very good & $\begin{array}{l}\text { Loosened riprap, sediment accumulation and forest } \\
\text { growth in the cut-off riverbed area }\end{array}$ & - \\
\hline Bank protection & $\mathrm{R}$ & $501.20-502.00$ & $\begin{array}{l}\text { Presently acts as a retaining wall, new loading } \\
\text { conditions, segments of the wall collapsed entirely }\end{array}$ & - & - \\
\hline Bank protection & $\mathrm{R}$ & $506.30-507.00$ & Very good, compact riprap & - & - \\
\hline Bank protection & $\mathrm{L}$ & $505.10-505.40$ & $\begin{array}{l}\text { Concrete slope facing washout and sliding, sediment } \\
\text { accumulation with fresh forest growth }\end{array}$ & - \\
\hline
\end{tabular}


noted, that top segments of the empirical rating curves practically do not exist in the design discharge value range (over $7000 \mathrm{~m}^{3} \cdot \mathrm{s}^{-1}$ ), because no such events have been observed in the recent decades.

Advanced erosion of the riverbed has additional indirect implications, which can greatly affect the valley within the levees. Lowering of the average yearly water level causes the crests of dams to be overflowed by water only accidentally during major floods, while they were intended to be under water several times each year. This promotes unhindered and rapid plant growth on top of the structures and in the entire area of the valley cut-off by the dams, which leads to even greater sediment deposition on the flood terraces. Thus, progressing deep erosion could be a contributing factor to the observed growth of a lush riparian forest, which is then protected as a part of "Natura 2000" network. This process results in an increase of stages during floods, as the vegetation obstructs water flow. Additionally, it might concentrate flood discharges inside the riverbed, promoting deep erosion also during high water levels.

The above-mentioned, relatively fast changes in the valley's geometry and its capacity to carry water discharges influence the design and maintenance of levees in two ways. Firstly, the constantly evolving relation between stages and discharges makes it difficult for the responsible hydrological authorities to assess and record their actual values on daily basis. As a result, the estimated design and control discharges considered while designing a structure are also likely less accurate. Secondly, changing shape and roughness of the hydraulic cross-section cause the originally estimated safe levee crest estimations to rapidly outdate (Table 1), as the previously assumed water levels corresponding to the design discharges also become obsolete. The most alarming process regarding the second aspect is likely the progressive and unhindered forest growth adjacent to the riverbed, especially considering the lately dominant summer floods, occurring when bushes and trees have leaves. It is estimated that presence of forests within the analysed river reach increases the stage corresponding to a $0.1 \%$ yearly exceeding probability discharge by approximately $0.5 \mathrm{~m}$, compared to a model assuming complete tree removal
(Artur Magnuszewski, Gutry-Korycka, \& Mikulski, $2012 b$ ). This shift of stage should be viewed in context of the safe levee crest elevation above the water level during the control discharge $\left(Q_{k}\right)$ (Table 1 , row 3 ). The responsible reaction to the plant growth promoted by erosion should likely be pruning rather than protecting.

\section{EROSION AND THE DESIGN OF WATER ENGINEERING STRUCTURES}

As presented before, the design requirements for the water engineering structures are based on a hydrological analysis. The fundamental relation between discharges and corresponding water levels is an important intrinsic feature of the analysed river crosssection, which depends on its geometry. It is clearly exemplified in this paper, that the geomorphology of river valleys can potentially change dramatically in time, which also causes the crucial discharge-water level relations to evolve. This means that a pre-design analysis based solely on historical data might become obsolete after a time considerably shorter than the design working life of the hydrotechnical structures. Formal regulations ignore these factors, though some researchers propose they should be predicted and considered to properly design and maintain structures (Naprawa, 2017). The riverbed reshaping processes occur in nature, but could be also enhanced by human activity, such as excessive debris mining or introduction of river regulation, especially when it is incorrectly designed. This means that the hydrotechnical structures and the environment coexist in a feedback loop, where the structures modify flow characteristics of the river, which in turn influences safety and technical condition of the same structures over time.

Another aspect crucial for proper river engineering is the post-regulation river supplies management. The way and degree to which the analysed river reach is mined for sand could serve as an example of defective environmental management, which disregards the particularities of the river reach and basic aspects of river engineering, both ecological and economic. Besides the deterioration of river regulation and flood safety, other consequences of deep riverbed erosion are also 
observed, such as hindered navigation (particularly ports, inaccessible during low water levels); water intake of the Siekierki CHP Plant, operated since 1961, stopped working due to lacking access to water and had to be moved adjacent to the river current to prevent shortages. It should be noted, that river regulation is not the only infrastructure located inside the valley - erosion could potentially negatively influence stability of bridges, boulevards etc. by changing the foundation conditions.

\section{SUMMARY}

The technical requirements and working conditions of water engineering structures are strongly dependent on the environment. The analysis of the selected Vistula river reach proves that these crucial environmental conditions may undergo significant transformations during a period shorter than the design working life of the structures, in this case due to deep riverbed erosion. The intensity of the phenomenon is enhanced by anthropogenic factors, such as introduction of river engineering or excessive sand mining. Due to the erosion, which also promotes forest growth on the flood terraces, some crucial assumptions necessary for the design of water engineering structures within the analysed reach gradually become obsolete. This results in an evidently bad technical condition of river engineering infrastructure, serious disruption in functionality thereof and the levees.

The design rules for water engineering structures might require an adequate inclusion of modelling of the significantly modified, post-regulation river regime. These should consider predictable anthropogenic factors changing the water flow and sediment transport characteristics. At the same time, controllable factors, such as mining and forest growth should be carefully monitored and regulated to avoid further deterioration of the structures.

This paper is based on data collected in 2016 as a part of a grant awarded by His Magnificence Rector of the Warsaw University of Technology.

\section{REFERENCES}

Fal, B., \& Dąbrowski, P. (2001). Dwieście lat obserwacji i pomiarów hydrologicznych Wisły w Warszawie. Cz. 1. Obserwacje stanów wody. Gospodarka Wodna, 11, 461-467.

Kocot, J. (2009). Zagospodarowanie Wisły w rejonie Warszawy. Gospodarka Wodna, 4, 146-147.

Kondolf, G. M. (1997). Hungry water: Effects of dams and gravel mining on river channels. Environmental Management, 21(4), 533-551. https://doi.org/10.1007/ s002679900048

Krukowicz, A. (2010). Stan zagrożenia powodziowego Warszawy i niektóre problemy związane z ochroną przed powodzią. Gospodarka Wodna, 3, 116-118.

Kuc, L. (2012). Wieloletnia zmienność reżimu hydrologicznego Wisty warszawskiej. (Praca magisterska). Politechnika Warszawska.

Kuźniar, P. (2011). Powódź w maju i czerwcu 2010 r. na warszawskim odcinku Wisły. Gospodarka Wodna, 2, 66-71.

Kuźniar, P., Bednarczyk, A., Krysiak, Ł., Rybczyński, A., \& Szablewski, B. (2017). Raport z wykonania grantu pt. Analiza i ocena skutków procesu erozji koryta Wisty warszawskiej na przykładzie odcinka rzeki w rejonie ujścia Wilanówki. Politechnika Warszawska.

Magnuszewski, A., Gutry-Korycka, M., \& Mikulski, Z. (2012a). Historyczne i współczesne warunki przepływu wód wielkich Wisły w Warszawie. Część I. Gospodarka Wodna, 1, 9-18.

Magnuszewski, A., Gutry-Korycka, M., \& Mikulski, Z. (2012b). Historyczne i współczesne warunki przepływu wód wielkich Wisły w Warszawie. Część II. Gospodarka Wodna, 2, 58-63.

Magnuszewski, A., \& Moran, S. (2014). Vistula River bed erosion processes and their influence on Warsaw's flood safety. IAHS-AISH Proceedings and Reports, 367 (December 2014), 147-154. https://doi.org/10.5194/piahs367-147-2015

Mamak, W., \& Zgierski, J. (1958). Regulacja rzek i potoków. Warszawa: Wydawnictwo Arkady.

Naprawa, S. (2017). Rozpoznawanie wpływu zmiennych parametrów przepływów w rozmywanych korytach rzek na projektowanie budowli hydrotechnicznych. Acta Scientiarum Polonorum, Architectura - Budownictwo, 16(3), 81-87. doi.org/10.22630/ASPA.2017.16.3.08 
Krysiak, Ł. (2018). The impact of riverbed erosion on the technical condition of water engineering structures: the example of Vistula river reach near the outlet of Wilanówka stream. Acta Sci. Pol. Architectura, 17 (4), 71-81. doi: 10.22630/ASPA.2018.17.4.42

Pomianowski, K. (1938). W sprawie jazu kanalizacyjnego na Wiśle pod Bielanami w Warszawie. Gospodarka Wodna, 4, 179-183.

Regionalny Zarząd Gospodarki Wodnej (1990s). Catalogue of typical structures used for river regulation [manuscript, in Polish].

Rozporządzenie Ministra Środowiska z dnia 20 kwietnia 2007 r. w sprawie warunków technicznych, jakim powinny odpowiadać budowle hydrotechniczne i ich usytuowanie. Dz.U. 2007 nr 86 poz. 579.
Scott, K. M. (1973). Scour and Fill in Tujunga Wash. - a Fanhead Valley in Urban Southern California - 1969 (Vol. 732). US Government Printing Office.

Żelaziński, J., Brański, J., Kadłubowski, A., \& Werski, S. (2005). Application of the CCHE models for explanation of factors causing deep erosion of Vistula River bed in Warsaw. Publ. Inst. Geophys. Pol. Acad. Sci., E-5, $87-113$

\section{EROZJA WGŁĘBNA A STAN TECHNICZNY BUDOWLI REGULACYJNYCH: PRZYKŁAD WARSZAWSKIEGO ODCINKA WIStY W REJONIE UJŚCIA WILANÓWKI}

\section{STRESZCZENIE}

Projektowanie i użytkowanie większości budowli wodnych muszą mieć charakter dynamiczny, gdyż powiązane są nierozerwalnie $\mathrm{z}$ występującymi w ich otoczeniu, zmiennymi warunkami środowiskowymi. W artykule zaprezentowano krótką analizę zjawiska erozji wgłębnej zachodzącego na warszawskim odcinku Wisły w rejonie ujścia Wilanówki. Przedstawiono wynikające z niego zmiany geomorfologii doliny, a także jego negatywny wpływ na stan techniczny i funkcjonalność rzecznych budowli regulacyjnych oraz wałów przeciwpowodziowych obecnych na analizowanym odcinku. Omówiono wybrane wymagania projektowe stawiane wobec budowli hydrotechnicznych zgodne z obowiązującym polskim prawem.

Słowa kluczowe: rzeczne budowle regulacyjne, wydobycie kruszywa, erozja 